\title{
Mindfulness and relaxation: the effects of a program with university hospital workers
}

\author{
Mindfulness e relaxamento: efeitos de um programa \\ com trabalhadores de um hospital universitário
}

lana Silva LEMOS' 1 iD $0000-0002-7022-4937$

Joana Vannessa Silva de CARVALHO' ${ }^{1}$ iD 0000-0002-5645-244X

Maria Theodora Gazzi MENDES ${ }^{1}$ (ID) 0000-0001-6790-1741

Ivani BRYS ${ }^{1}$ (iD) 0000-0001-7859-1160

\begin{abstract}
Our study compared the effects of mindfulness and relaxation interventions on stress, quality of life, resilience, and mindfulness levels. A total of 29 workers, recruited at a university hospital in the northeastern region of Brazil and distributed in two groups: Mindfulness (89.5\% female, age mean $37.5 \pm 6.23$ years old); and Relaxation (90.0\% female, age mean $34.2 \pm$ 8.66). After eight weeks of daily mindfulness or relaxation practices, both groups significantly reduced the perceived stress and stress at work, and increased their mindfulness and resilience levels, as well as the physical and psychological quality of life domains. Our results suggest that both interventions may be effective in the organizational environment, assisting in health promotion and increasing the ability of individuals to recover from an adversity (resilience).
\end{abstract}

Keywords: Occupational stress; Psychological resilience; Quality of life.

\section{Resumo}

Este estudo comparou os efeitos de intervenções baseadas em mindfulness e em relaxamento sobre níveis de estresse, qualidade de vida e resiliência. Participaram do estudo 29 trabalhadores de um hospital universitário do nordeste do Brasil, distribuídos em dois grupos: Mindfulness (89,5\% mulheres, média de idade 37,5 \pm 6,23); e Relaxamento (90,0\% mulheres, média de idade 34,2 $\pm 8,66)$. Após oito semanas de práticas diárias dessas internveções, ambos os

\section{$\nabla \nabla \nabla$}

1 Universidade Federal do Vale do São Francisco, Programa de Pós-Graduação em Psicologia, Grupo de Pesquisa em Neurociências e Psicologia Experimental. Av. José de Sá Maniçoba, s/n., Centro, 56304-917, Petrolina, PE, Brasil. Correspondence to: I BRYS. E-mail: <ivani.brys@univasf.edu.br>.

How to cite this article

Lemos, I. S., Carvalho, J. V. S., Mendes, M. T. G., \& Brys, I. (2021). Mindfulness and relaxation: the effects of a program with university hospital workers. Estudos de Psicologia (Campinas), 38, e190128. https://doi.org/10.1590/1982-0275202138e190128 
grupos reduziram significativamente o estresse percebido e aumentaram os niveis de mindfulness, de resiliência e os domínios físico e psicológico da qualidade de vida. Nossos resultados sugerem que elas podem ser eficazes no ambiente organizacional, auxiliando na promoção da saúde e aumentando a capacidade dos indivíduos de se recuperarem da adversidade (resiliência).

Palavras-chave: Estresse ocupacional; Resiliência psicológica; Qualidade de vida.

Stress is a response of the organism to an exterior or interior stimulus that provokes reactions on physiological and psychological levels. Depending on the severity, type, and duration of the stimulus, the stress response can produce alterations in the organism that can have negative effects to the individual's health and even result in death. People who are in stressful environments, tend to present higher stress levels and are more prone to develop multiple health disorders (Yaribeygi, Panahi, Sahraei, Johnston, \& Sahebkar, 2017).

Occupational environment can contribute to high stress levels and consequently bring negative effects to an individual's health. This is understandable, given that the organizational environment offers psychosocial risks to workers which are related to the content, organization, and management of work and may have negative effects on physical, social, and psychological levels (Fernandes \& Pereira, 2016).

Mental disorders were the third cause for work incapacity between 2012 and 2016 in Brazil (Ministério da Fazenda, 2017); a total of 178,268 disability insurance pensions were computed due to mental disorders in 2017 in the country (Ministério do Trabalho, 2018). In this scenario, one segment of professionals that show high occupational stress levels is the one of health professionals, especially those working in the hospital environment (Assis, Caraúna, \& Karine, 2015; Rosado, Russo, \& Maia, 2015). The occupational environments of university hospitals are characterized by long working hours, scarce resources, work overload, and low salaries; they have been associated with the workers' high stress levels, as well as high absenteeism levels related to the development of mental disorders and musculoskeletal diseases (Barros, 2016; Silveira \& Grisotti, 2011).

The development of interventions that can be applied in the occupational context of hospitals, aiming at promoting health, quality of life, and the reduction of stress of hospital workers is therefore an urgent need. Previous studies have shown that mindfulness and relaxation-based interventions might be beneficial for this population. Both can be used as interventions aiming to improve psychological health and coping styles, to build positive states of mind, and to reduce stress (Hugh-Jones, Rose, Koutsopoulou, \& Simms-Ellis, 2018; Kersemaekers et al., 2018).

Mindfulness refers to a state of consciousness created when individuals focus their attention on the present moment (Kotsou, 2015). The level of mindfulness can be improved through a systematic training of attention and self-control accompanied by an attitude of acceptance and openness to experiences. Contemplative practices, such as meditation and yoga, are types of practices that increase the state of mindfulness, which can lead to functional and structural changes in the brain (Davidson et al., 2012).

Mindfulness interventions have been demonstrated to alleviate chronic workplace stress (job burnout) of health teachers and other professionals (Luken \& Sammons, 2016). Beyond workplace stress reduction, Mindfulness-Based Interventions (MBI) increased the ability to manage stress, as shown in a study with 44 resident doctors who participated of a 10-week mindfulness training (Ireland et al., 2017). Other benefits of $\mathrm{MBI}$ are reduced blood pressure, improvement on emotion management, and increased well-being (Jansen, Heerkens, Kuijer, van der Heijden, \& Engels, 2018; Taylor et al., 2016; Wongtongkam, Krivokapic-Skoko, Duncan, \& Bellio, 2017).

Relaxation can be defined as a state of calmness, relief of body tension, and as an opposite reaction to stress (Jain et al., 2007). When individuals are relaxed, they show a normalization of arterial pressure, decreased respiratory and heart rates, increased skin temperature, and dilation of blood vessels, among other

2 physiological reactions (Figueiredo, 2002; Kwekkeboom \& Gretarsdottir, 2006). 
Relaxation-Based Interventions (RBI) have shown evidences of being a helpful stress-management strategy for health care professionals (Veiga et al., 2019). Some of the most commonly used practices involve progressive muscle relaxation, visualization, and rhythmic breathing (Jain et al., 2007; Kwekkeboom \& Gretarsdottir, 2006). Benefits associated with these practices include stress, anxiety, and depression reduction (Jain et al., 2007), improved coping ability to manage stress, and enhanced self-control (Li et al., 2015).

Mindfulness and relaxation practices are associated with quality of life improvements (HassanpourDehkordi \& Jalali, 2016; Shahriari, Dehghan, Pahlavanzadeh, \& Hazini, 2017), which is the way the individual perceives the place he or she occupies in life, involving several domains (physical, psychological, social relations, and the environment). Quality of life is also defined as a state of well-being and has been used to assess population health levels (Almeida-Brasil et al., 2017). Therefore, if an intervention can improve an individual's quality of life, it might be helping to promote health and prevent sickness.

Mindfulness-based interventions and RBI are also associated with increased resilience levels, which is the adaptive response to stressful or negative situations that allow the individual to overcome an adversity and get healthy (Kaplan, Bergman, Christopher, Bowen, \& Hunsinger, 2017; Knorst, 2012). According to Keye and Pidgeon (2013), resilience is a positive adjustment to distressing events, and it helps to deal with adverse events in the future. It has been shown that nurses with higher resilience levels were protected from emotional exhaustion (Rushton, Batcheller, Schroeder, \& Donohue, 2015). Improving resilience not only helps the individual to deal with stressful events at the present moment but also increases the chance of successfully managing stressful events in the future. Therefore, with resilience, individuals are more prone to better adapt to a difficult situation (Chimitorz et al., 2018).

Mindfulness and relaxation-based interventions have been shown to be effective and low-cost, and can easily be adapted to organizational environments. Therefore, the aim of this study was to investigate the effects of mindfulness and relaxation-based interventions lasting a total of eight weeks, and with daily practices from ten to twenty minutes on stress, quality of life, resilience, and mindfulness levels of workers from a university hospital located in the city of Petrolina, in the state of Pernambuco, Brazil. Our hypothesis was that both interventions would reduce stress, improve quality of life and resilience, and only MBI would improve the mindfulness levels of the participants.

\section{Method}

\section{Participants}

A sample of 29 individuals, permanent workers at the Hospital de Ensino Doutor Washington Antônio de Barros - Universidade do Vale do São Francisco (HU-UNIVASF, Doctor Washington Antônio de Barros Teaching Hospital of the Federal University of Vale do São Francisco) of the administrative or health care sectors, participated in this study. The recruitment of participants was performed in the period of one month through posters at the hospital and via email, and applications were received through an online form.

Participants were randomly distributed in two groups (mindfulness, $n=18$ and relaxation, $n=11$ ). The total number of participants who completed the intervention phase was 15. The MBI group consisted of 7 workers, from both sectors of the hospital, in which the majority were women $(n=6)$, with a mean age of 38.6 years (minimum: 26 and maximum: 47, SD $=7.4$ ), and who were either nursing technicians $(n$ $=5$ ) or administrative assistants $(n=2)$. The RBI group consisted of 8 workers, all female, also from both 
sectors, whose mean age was 35.9 years (minimum: 24 and maximum: 49, $S D=8.9$ ), and who were nursing technicians ( $n=3)$; an economist $(n=1)$; an administrator $(n=1)$; a psychologist $(n=1)$; and an administrative assistant $(n=2)$. A CONSORT Flow Diagram showing all the steps of the study is presented on Figure 1 . The demographic information for each group is presented in Table 1.

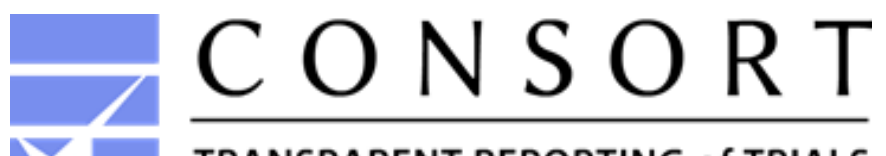

TRANSPARENT REPORTING of TRIALS

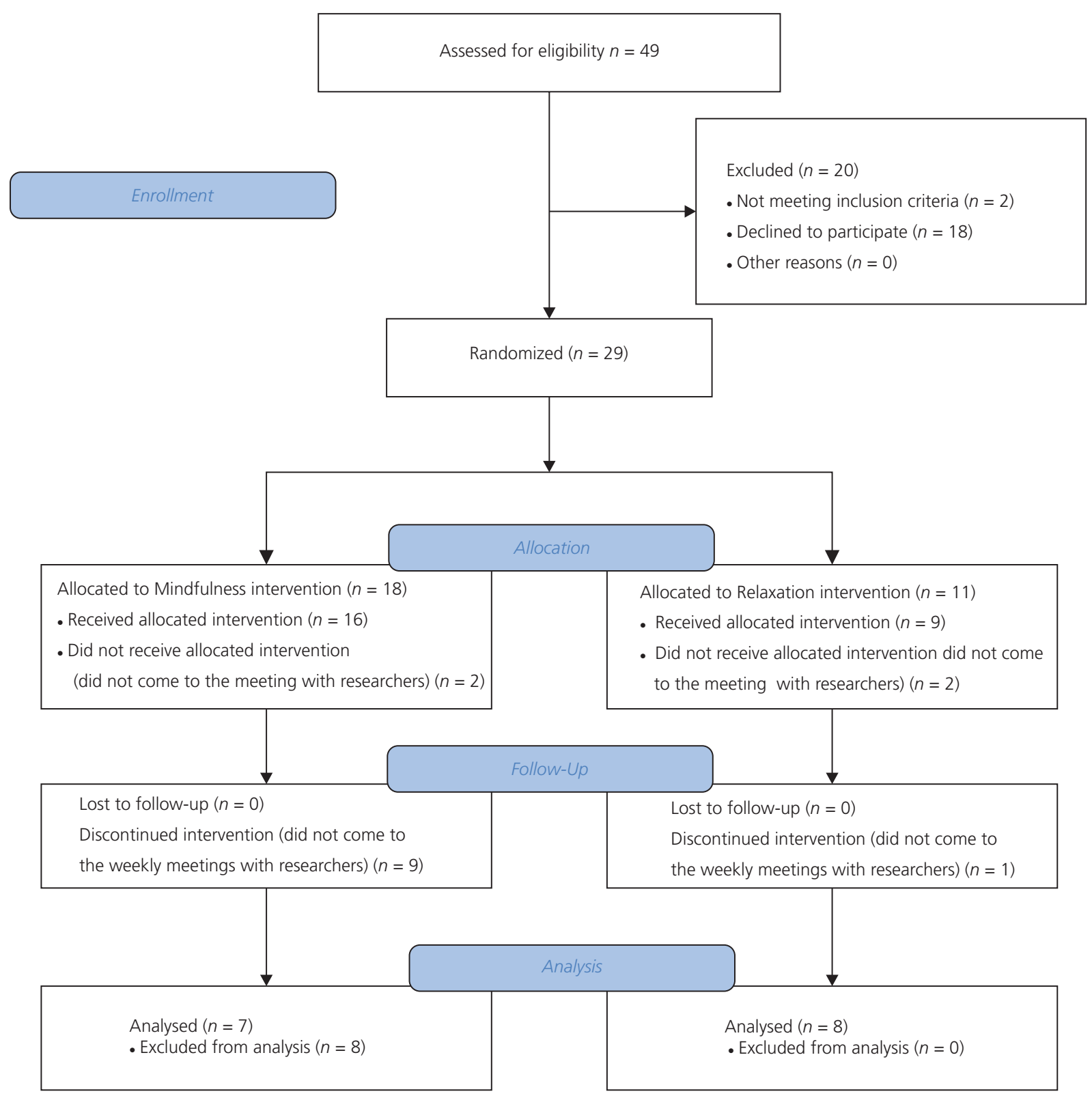

Figure 1. Consort Flow Diagram showing how the population was recruited and screened during the study. 
Demographic information of the participants of the intervention groups (MBI and RBI)

\begin{tabular}{|c|c|c|c|c|c|c|}
\hline \multirow{2}{*}{ Factors } & \multicolumn{3}{|c|}{ Mindfulness } & \multicolumn{3}{|c|}{ Relaxation } \\
\hline & Mean & Standard Deviation & $\%$ & Mean & Standard Deviation & $\%$ \\
\hline Age (years) & 37.5 & 6.23 & & 34.2 & 8.66 & \\
\hline Number of children & 1.7 & 0.9 & & 1.3 & 0.5 & \\
\hline $\begin{array}{l}\text { Predominant gender } \\
\text { Female } \\
\text { Marital status }\end{array}$ & & & 89.5 & & & 90.0 \\
\hline $\begin{array}{l}\text { Married } \\
\text { Educational level }\end{array}$ & & & 42.1 & & & 50.0 \\
\hline $\begin{array}{l}\text { Undergraduate } \\
\text { Specialization }\end{array}$ & & & 31.6 & & & 40.0 \\
\hline $\begin{array}{l}\text { Work sector } \\
\text { Health care } \\
\text { Administrative }\end{array}$ & & & 94.7 & & & 60.0 \\
\hline
\end{tabular}

Note: The other values correspond to the predominance of each factor.

MBI: Mindfulness-Based Interventions; RBI: Relaxation-Based Interventions.

\section{Instruments}

The language used in all instruments was Brazilian Portuguese. All scales were previously validated for the Brazilian population and were applied before and after the intervention.

Registration form and Demographic Questionnaire: Available in online format, designed to register participants' demographic information.

Audio Recordings for Mindfulness and Relaxation Practices: Divided between: the practice of body scanning (MBI group); progressive muscle relaxation (RBI group); meditation focusing on breath - 10 and 20 minutes (MBI group); loving-kindness meditation (MBI group) and relaxation through visualization (I, II, and III - RBI group). Each group had a total of 4 practices, ranging between 10 and 20 minutes. The audio recordings were based on techniques usually present in mindfulness and relaxation protocols (such as body scanning or progressive muscle relaxation) and were elaborated by the researchers under the supervision of an experienced professional in the field of contemplative practices. All the audios were recorded in a studio and narrated by one of the authors of the present study, who has eight years of experience as a certified instructor of yoga practices (the content of the audios are available upon request).

Perceived Stress Scale (PSS-10): Comprised of 10 items that are used to assess the subject's perceived stress in the last month, with six positive and four negative items, answered in a Likert-type scale of frequency. The version used in this study was translated and adapted to Brazilian Portuguese by Luft, Sanches, Mazo, and Andrade (2007).

Scale of Stress at Work (SSW): Composed of 13 items (Likert-type Scale) that assessed the level of stress related to work. The version used was developed and validated by Paschoal and Tamayo (2004).

Mindful Attention Awareness Scale: Composed of 15 items (Likert-type Scale), which assesses the level of awareness and mindfulness of the subject. The Brazilian version of the Mindful Attention Awareness Scale was validated by Barros, Kozasa, Souza, and Rozani (2015) was used.

Resilience Scale - developed by Wangnild and Young: Composed of 25 items (Likert-type Scale) which assesses the positive psychosocial adjustment during important life events. The version adapted to Brazilian Portuguese by Pesce et al. (2005) was used. 
World Health Organization Quality of Life Instrument (WHOQOL): Developed by the World Health Organization (WHOQOL Group, 1994). We used the brief version WHOQOL-BREF (Qualidep, 1995). The validation study to Brazilian Portuguese was conducted by Fleck et al. (2000).

\section{Procedures}

The research was approved by the Universidade Federal do Vale do São Francisco (UNIVASF, Federal University of Vale do São Francisco). Ethics Committee, CAAE: 64237417.1.0000.5196, and followed all the guidelines of Resolution 510/2016, which regulates research in the humanities sciences in Brazil. All subjects gave their written consent regarding the participation in the study that composes this article.

Data collection and interventions were carried out in a room of UNIVASF, located in Petrolina (PE). This location was chosen because it was near the workplace of the participants, contained the appropriate materials for the performed practices, and provided greater comfort and privacy to the individuals. After filling out the online registration form, participants were invited for a meeting, when general information about the research was set out, and the Consent Form was signed by all participants. Following this, the scales $(3-7)$ were applied, and participants were randomly distributed in two groups: $\mathrm{MBI}$ and $\mathrm{RBI}$.

\section{Intervention}

The participants received a CD containing four audio tracks according to the type of practices they performed: mindfulness or relaxation. As the total intervention period was of eight weeks' duration, each of the four practices was repeated for two weeks. In the first two weeks of the intervention, the MBI group performed body scanning (with a total duration of $20 \mathrm{~min}$ ) and the RBI group performed progressive muscle relaxation (with a total duration of $20 \mathrm{~min}$ ). At weeks three and four, the MBI group performed a meditation practice focused on breathing (total duration of $10 \mathrm{~min}$ ) and the RBI group performed a relaxation practice through visualization I (total duration of $10 \mathrm{~min}$ ). At weeks five and six, the MBI group performed a meditation practice focused on breathing (total duration of $20 \mathrm{~min}$ ) and the RBI group performed a relaxation practice through visualization II (total duration of $20 \mathrm{~min}$ ). In the last weeks of intervention (seven and eight), the $\mathrm{MBI}$ group practiced loving-kindness meditation (duration of $10 \mathrm{~min}$ ) and the RBI group practiced relaxation through visualization III (total duration of $10 \mathrm{~min}$ ).

Weekly meetings were held (over the eight weeks of the intervention) with participants and researchers, in which additional information on practices and postures were provided. For control purposes, participants were asked to report if they had missed any of the daily practices of that week. At the end of every weekly meeting, participants were instructed to continue performing their daily practices individually, at the location of their choice (in a comfortable and quiet location, free of interruptions).

\section{Data analysis}

Data analyses were performed using the IBM ${ }^{\circledR}$ SPSS ${ }^{\circledR}$ Software (version 21). A Mixed-Design Analysis of Variance (ANOVA) was performed for verification and comparison of the effects of the interventions, with the type of intervention as a factor between groups, and time as a factor within groups. A t-test for independent samples was performed to compare the workers from the administrative and health care sectors. The criterion for statistical significance was $p<0.05$. 


\section{Results}

\section{Pre-intervention phase}

A total of 29 workers from both sectors (health care and administrative) of HU-UNIVASF, without previous experience with mindfulness or relaxation practices, participated in the pre-intervention phase of the study. Hospital workers had relatively high stress levels, mean mindful attention, resilience, and quality of life levels, as shown in Table 2. No statistically significant differences were found between workers from the administrative and health care sectors. The reference values for each scale are shown in Table 3.

Table 2

Initial stress (perceived and at work), mindfulness, resilience, and quality of life levels of HU-UNIVASF workers from both sectors (health care and administrative)

\begin{tabular}{|c|c|c|c|}
\hline Sectors & Mean & Standard Deviation & $\alpha$ \\
\hline Perceived Stress & 19.10 & 6.67 & 0.87 \\
\hline Stress at Work & 2.50 & 0.61 & 0.82 \\
\hline Mindful Attention & 53.93 & 14.38 & 0.89 \\
\hline Quality of Life (physical domain) & 59.41 & 19.31 & 0.87 \\
\hline Quality of Life (psychological domain) & 61.03 & 16.17 & 0.79 \\
\hline Quality of Life (social relations domain) & 62.93 & 16.54 & 0.57 \\
\hline Quality of Life (environment domain) & 60.62 & 13.31 & 0.73 \\
\hline
\end{tabular}

Note: $\alpha$ : Cronbach's Alpha.

Table 3

Reference values to indicate the levels of each factor assessed

\begin{tabular}{|c|c|c|}
\hline Scales & Reference values & $a$ \\
\hline Perceived Stress Scale ${ }^{1}$ & The higher the mean, the higher the stress level & 0.83 \\
\hline Scale of Stress at Work ${ }^{2}$ & Presence of work-related stress $\geq 2.5$ & 0.85 \\
\hline Mindful Attention Awareness Scale ${ }^{3}$ & The closer the value is to 90 , the higher the level of mindful attention & 0.83 \\
\hline Resilience Scale, developed by Wangnild and Young ${ }^{4}$ & The closer the value is to 175 , the higher the resilience level & 0.80 \\
\hline World Health Organization Quality of Life Instrument ${ }^{5}$ & Poor (0 - 33); Mean (34 - 67); Good (68 - 100) & 0.77 \\
\hline
\end{tabular}

Note: ${ }^{1}$ (Luft et al., 2007; Remor, 2006); ${ }^{2}$ (Paschoal \& Tamayo, 2004); ${ }^{3}$ (Atanes et al., 2012; Barros et al., 2015); ${ }^{4}$ (Pesce et al., 2005; Slomka, 2011); ${ }^{5}$ (Fleck et al., 2000; Talarico, 2013).

a: Cronbach's Alpha.

\section{Post-intervention phase}

A dropout rate of $48.3 \%$ was observed over the course of the interventions. The MBI group presented a higher dropout rate (63.1\%) in comparison with the RBI group (20.0\%). Most participants (13) who dropped out were from the health care sector (nurses, doctors, and nursing technicians).

At the end of the intervention period, it was expected that the participants of both groups $(\mathrm{MBI}$ and $\mathrm{RBI}$ ) had reduced their stress levels. In fact, as evidenced in Figure 2, there was a significant reduction in the perceived stress $\left[F(1.13)=12.96, p=0.003, \eta_{p}{ }^{2}=0.499\right]$ and stress at work $[F(1.13)=17.44, p=0.001$, $\eta_{p}^{2}=0.573$ ] levels in both groups. There was no interaction between time and type of intervention $(p>0.05)$.

The ANOVA test showed that the interventions of mindfulness and relaxation produced a significant increase in mindfulness levels $\left[F(1.13)=7.64, p=0.016, \eta_{p}^{2}=0.370\right]$ and resilience $[F(1.13)=6.96, p=0.02$, $\left.\eta_{p}^{2}=0.349\right]$. However, there was no difference between the types of intervention, nor interactions between the type of intervention and time factors $(p>0.05)$. 
A

Perceived stress

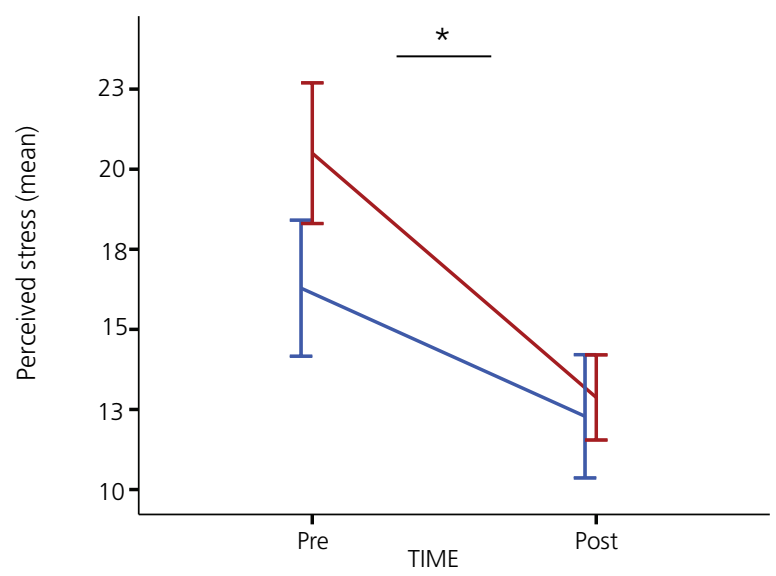

C

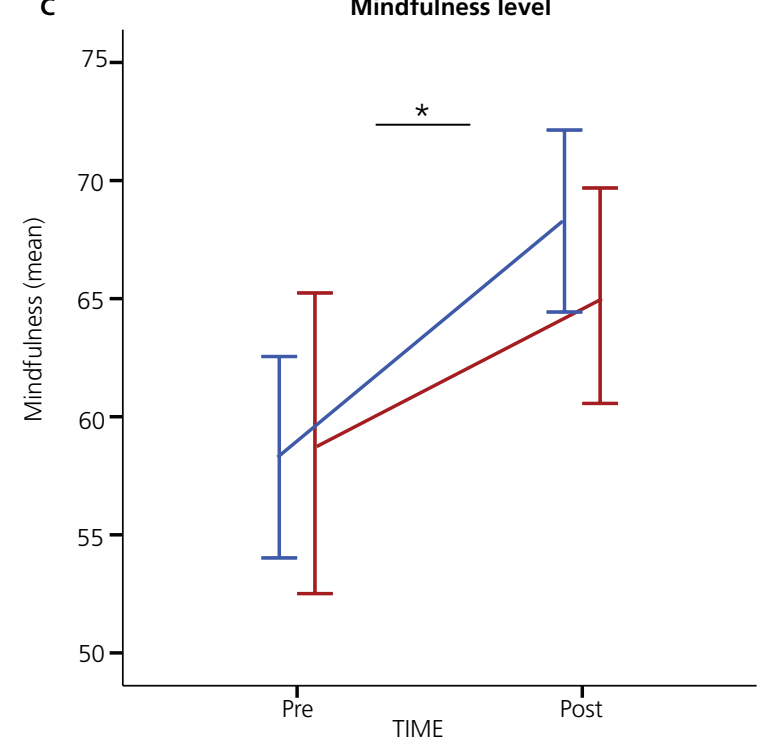

E

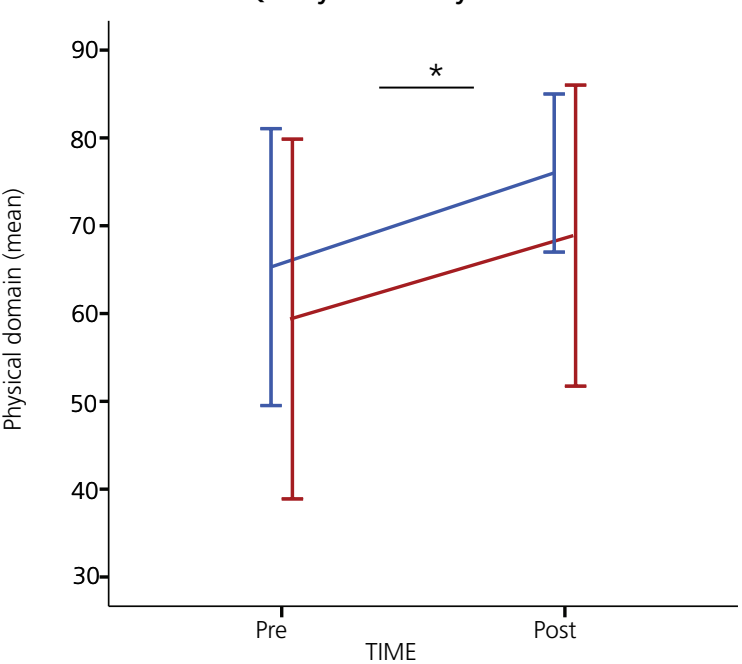

B

Stress at work

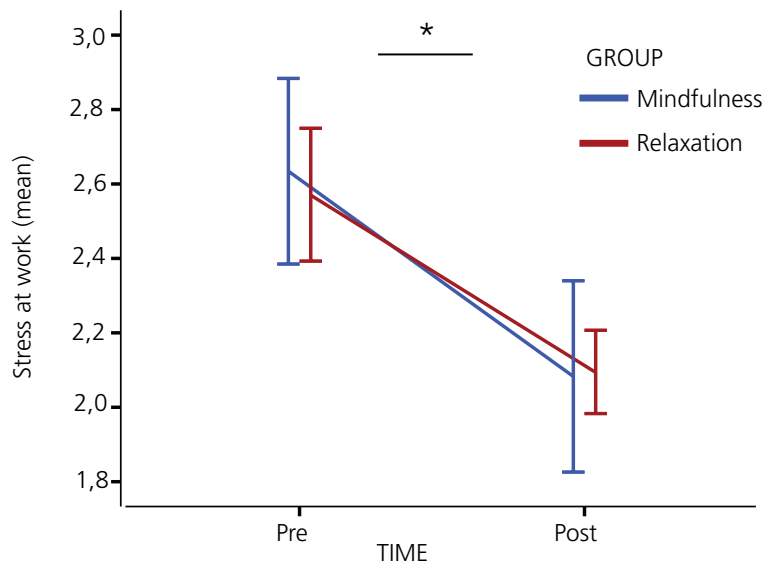

D

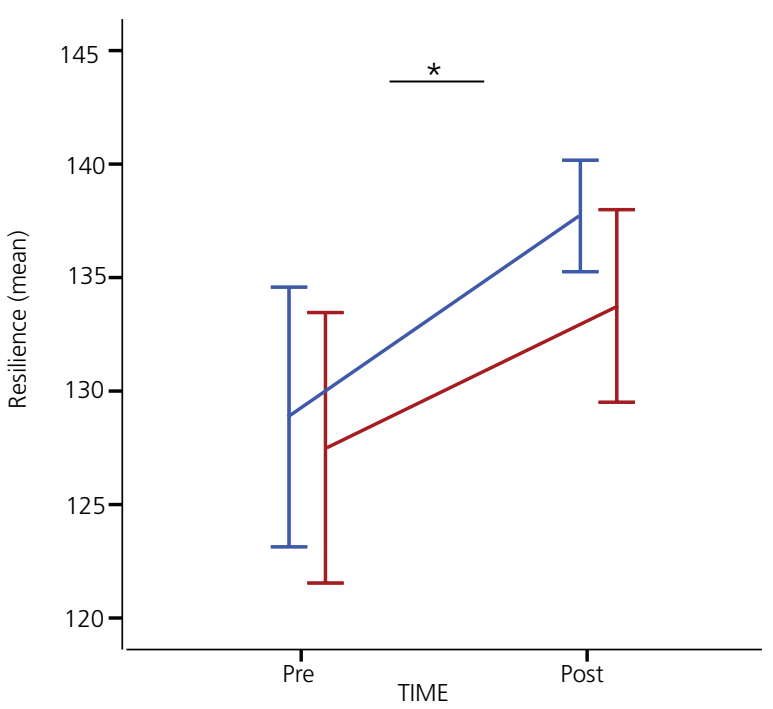

F

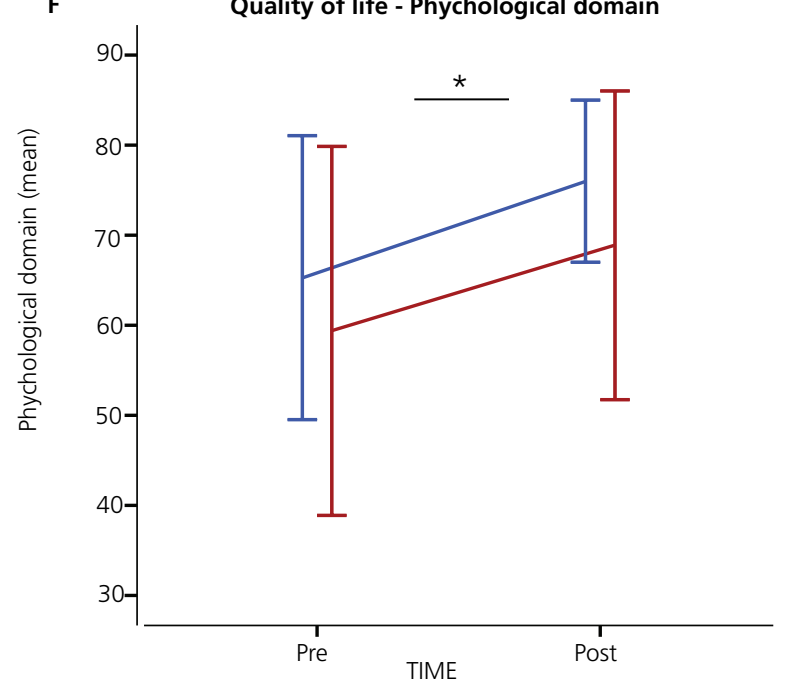

Figure 2. Mindfulness and relaxation practices reduce stress and improve quality of life, mindfulness levels, and resilience.

Note: "Both types of interventions significantly reduced the participants' stress levels $(p<0.05)$; and significantly increased the participants' mindful attention and resilience $(p<0.05)$, as well as the quality of life in the physical and psychological domains $(p<0.05)$.

Means of perceived stress levels (A) and stress at work (B); mindfulness (C) and resilience (D); quality of life in the physical domain (E); and psychological domain $(F)$, before and after interventions. 
Both interventions ( $\mathrm{MBI}$ and $\mathrm{RBI}$ ) resulted in a significant increase in the quality of life physical $[F$ $\left.(1.13)=12.30, p=0.004, \eta_{p}{ }^{2}=0.486\right]$ and psychological domains $\left[F(1.13)=5.16, p=0041, \eta_{p}{ }^{2}=0.284\right]$ of the participants, as shown in Figure 2. The areas of social relations and environment also showed an improvement, but the values were not statistically significant $(p>0.05)$. According to the correction parameters of the WHOQOL-BREF (Table 2), the means obtained in the physical and psychological domains after interventions in both groups were at a good level, i.e. between 68 and 100. There was no difference between the types of intervention, nor interactions between the type of intervention and time factors $(p>0.05)$.

\section{Discussion}

This study investigated the stress, mindfulness, resilience, and quality of life levels of a university hospital workers. The results showed that these professionals have relatively high stress and mean mindfulness, resilience, and quality of life levels. There were no differences between workers from the administrative or health care sectors, suggesting that the hospital environment might be stressful, even for the professionals who do not deal directly with patients. Additionally, two types of interventions were carried out (MBI and $\mathrm{RBI}$ ) and the pre- and post-intervention comparisons suggested that both may be effective in reducing stress and increasing mindfulness, resilience, and quality of life levels of hospital workers.

This finding is consistent with the literature that has pointed out that there are no major differences between the beneficial effects of an $\mathrm{MBI}$ and an RBI when compared with a control group of participants in the waiting list (Jain et al., 2007; Josefsson, Lindwall, \& Broberg, 2014). According to Virgili (2015), there is little evidence that mindfulness-based interventions have greater effectiveness for reducing stress, when compared with other types of intervention, such as yoga or relaxation.

Regarding the mindfulness levels, and following our literature findings, our initial hypothesis was that both interventions would be able to reduce stress, improve quality of life and resilience, but only the $\mathrm{MBI}$ would improve the mindfulness levels. What we found, however, is that both interventions may have beneficial effects on the level of mindfulness of the participants.

There are still few studies that aim to explain this happening but one factor that might have contributed to this result is the similarity between the practices of both interventions, especially the practice of body scanning and progressive muscle relaxation. Both lead the individuals to focus the attention on different parts of the body, one at a time, which might cause the development of the mindfulness state even when using relaxation practices (Josefsson et al., 2014).

In relation to quality of life, the two areas that showed significant differences were the psychological and the physical domains. According to Talarico (2013), some of the facets of the psychological domain are: positive feelings, thinking, learning, memory, concentration, and self-esteem. In the physical domain, the facets are: pain and discomfort, sleep and rest, and the capability to work. This corroborates what some studies have found about reduction of pain and improvement in sleep quality with both relaxation (Saeedi, Ashktorab, Saatchi, Zayeri, \& Amir, 2012; Tsai, Chen, Lai, Lee, \& Lin, 2007) and mindfulness practices (Visser, Hirsch, Brown, Ryan, \& Moynihan, 2015; Zeidan, Grant, Brown, McHaffie, \& Coghill, 2012).

Another important finding, that also corroborates with what has been found in previous studies, is related to the duration of interventions ( 8 weeks), the practice time (mean of 15 minutes), and the benefits produced by them (Paulik, Simcocks, Weiss, \& Albert, 2010; Song \& Lindquist, 2015). The results of the present study suggest that daily practices, from 10 to 20 minutes, over eight weeks, might be appropriate and sufficient to promote positive changes. Some MBI, with practices of similar duration have shown to be effective and appropriate to the organizational setting (Virgili, 2015), indicating that even short periods of practice (mindfulness and relaxation) might be beneficial. 
The effects of a mindfulness program can persist along the years. Solhaug et al. (2019) demonstrated that the benefits of a seven-week, mindfulness-based stress reduction program were observed four years later in a sample of university students. The participants showed improved scores of mental distress and coping strategies, which suggests that meditation practice is a positive predictor of long-term mindfulness levels. Similar outcomes were found by Braun, Kinser, Carrico, and Dow (2019), who investigated the benefits of a mindfulness-based intervention, in a follow-up study of six to 18 months' duration. Their findings show that three elements of mindfulness increased in the long run: acting with awareness, nonreactivity, and nonjudging. These results show the importance of follow-up studies when investigating the effects of $\mathrm{MBI}$ and point out that the inexistence of long-term assessments is an important limitation of the present study.

By the end of this study, $48.3 \%$ of the participants had dropped out without completing all proposed practices, which limits the generalization and the inferences of the results for the studied population. The fact that each participant of the study received a CD containing the four audio tracks, according to the type of practices they performed (mindfulness or relaxation), already on the first day of intervention is an important methodological issue that may have contributed to the high dropout rate. This gave participants the possibility of performing the daily practices individually at the location of their choice over the eight weeks without attending the weekly meetings with the researchers.

Most participants who dropped out were part of the health care sector known for the high workload, long working hours, and sleep deprivation. The intense workload of the participants and the unavailability of an appropriate room in the building of the university hospital where the meetings with the researchers could have been held may have also contributed to the low attendance of the participants. In order to prevent excessive dropouts, it is important that future interventions take place at the participants' workplace and on their breaks.

The literature points out that other factors, such as social desirability (Ribas, Moura, \& Hutz, 2004) and learning (Oliveira, Trezza, Busse, \& Jacob Filho, 2014), might by themselves affect the low response of the participants to the assessment instruments. The inclusion of a third group, which would have not performed any practices (those on the waiting list, for example), would have made it possible to assess the effects of time, social desirability and learning of the scales in the responses of the participants. It is also important to clarify that this study was not submitted to a clinical trial registry before data collection.

Future studies investigating the effects of relaxation-based interventions on mindfulness levels could help us to understand how this type of practice affects this state of consciousness. The use of neuroimaging techniques such as functional magnetic resonance imaging can unveil the neural mechanisms of benefits associated to relaxation techniques and contribute to investigate differences between the underlying mechanisms of relaxation and mindfulness practices.

\section{Conclusion}

The results of the present study suggest that professionals of university hospitals may be at psychosocial risk due to stress levels associated with their work contexts. The development of interventions, such as those carried out in this study, is important to prevent the occurrence of health problems. This study adds to the growing literature on the subject, that mindfulness and relaxation practices are cost-effective interventions that can be easily adapted to different work contexts, including the hospital environment. 


\section{Acknowledgments}

The authors would like to thank Jennifer Lee Palmer and Sandra Lee Palmer for their careful and valuable revision of the manuscript.

\section{Contributors}

I. S. LEMOS, M. T. G. MENDES, and I. BRYS contributed to the conception and design, data analysis, interpretation, writing, discussion of the results, review, and approval of the final version of the article. J. V. S. CARVALHO contributed to the conception, data collection, interpretation, and approval of the final version.

\section{References}

Almeida-Brasil, C. C., Silveira, M. R., Silva, K. R., Lima, M. G., Faria, C. D. C. M., Cardoso, C. L., ... Ceccato, M. G. B. (2017). Qualidade de vida e características associadas: aplicação do WHOQOL-BREF no contexto da atenção primária à saúde. Ciência e Saúde Coletiva, 22(5), 1705-1716. https://doi.org/10.1590/1413-81232017225.20362015

Assis, M. R., Caraúna, H., \& Karine, D. (2015). Análise do estresse ocupacional em profissionais da saúde. Conexões Psi, 3(1), 62-71. Recuperado de https://core.ac.uk/download/pdf/229105355.pdf

Atanes, A. C. M., Barros, V. V., Ronzani, T., Leonelli, L. B., Kozasa, E. H., Andreoni, S., \& Demarzo, M. M. P. (2012). Validade e confiabilidade da Escala de Atencão Plena e Consciência (MAAS) e Questionário das Cinco Facetas de Mindfulness (FFMQ) entre profissionais da Atenção Primária à Saúde. Revista Brasileira de Medicina de Família e Comunidade, 7(1), 78. https://doi.org/10.5712/rbmfc7(1)642

Barros, P. A. S. (2016). Nível de estresse e coping de enfermeiros do setor de clínica cirúrgica de um hospital universitário público em Fortaleza - Ceará (Dissertação de mestrado não-publicada). Universidade Federal do Ceará, Fortaleza, Fortaleza. Recuperado de http://www.repositorio.ufc.br/handle/riufc/18188

Barros, V. V., Kozasa, E. H., Souza, I. C. W., \& Ronzani, T. M. (2015). Validity evidence of the brazilian version of the Mindful Attention Awareness Scale (MAAS). Psicologia: Reflexão e Crítica, 28(1), 87-95. https://doi.org/10.1590/16787153.201528110

Braun, S. E., Kinser, P., Carrico, C. K., \& Dow, A. (2019). Being mindful: a long-term investigation of an interdisciplinary course in mindfulness. Global Advances in Health and Medicine, 8, 1-12. https://doi.org/10.1177/2164956118820064

Chmitorz, A., Kunzler, A., Helmreich, I., Tüscher, O., Kalisch, R., Kubiak, T., ... Lieb, K. (2018). Intervention studies to foster resilience: a systematic review and proposal for a resilience framework in future intervention studies. Clinical Psychology Review, 59, 78-100. https://doi.org/10.1016/j.cpr.2017.11.002

Davidson, R. J., Dunne, J., Eccles, J. S., Engle, A., Greenberg, M., Jennings, P., ... Vago, D. (2012). Contemplative practices and mental training: prospects for American education. Child Development Perspectives, 6(2), 146-153. https://doi. org/10.1111/j.1750-8606.2012.00240.x

Fernandes, C., \& Pereira, A. (2016). Exposure to psychosocial risk factors in the context of work: a systematic review. Revista de Saúde Pública, 50(24), 1-15. https://doi.org/10.1590/S1518-8787.2016050006129

Figueiredo, L. R. U. (2002). Relaxamento: uma proposta de intervenção com gestantes hipertensas (Dissertação de mestrado não-publicada). Universidade de São Paulo. Recuperado de https://doi.org/10.11606/D.59.2002.tde-19092004-220116

Fleck, M. P. A., Louzada, S., Xavier, M., Chachamovic, E., Vieira, G., Santos, L., \& Pinzon, V. (2000). Aplicação da versão em português do instrumento abreviado de avaliação da qualidade de vida "WHOQOL-bref". Revista de Saúde Pública, 34(2), 178-183. https://dx.doi.org/10.1590/S0034-89102000000200012

Hassanpour-Dehkordi, A., \& Jalali, A. (2016). Effect of progressive muscle relaxation on the fatigue and quality of life among Iranian aging persons. Acta Med Iran, 54(7), 430-436. Retrieved from https://pubmed.ncbi.nlm.nih.gov/27424013/

Hugh-Jones, S., Rose, S., Koutsopoulou, G. Z., \& Simms-Ellis, R. (2018). How is stress reduced by a workplace mindfulness intervention? A qualitative study conceptualizing experiences of change. Mindfulness, 9, 474-487. https://doi. org/10.1007/s12671-017-0790-2

Ireland, M. J., Clough, B., Gill, K., Langan, F., O'Connor, A., \& Spencer, L. (2017). A randomized controlled trial of mindfulness to reduce stress and burnout among intern medical practitioners. Medical Teacher, 39(4), 409-414. https://doi.org/10.1080/0142159X.2017.1294749

Jain, S., Shapiro, S. L., Swanick, S., Roesch, S. C., Mills, P. J., Bell, I., \& Schwartz, G. E. R. (2007). A randomized controlled trial of mindfulness meditation versus relaxation training: effects on distress, positive states of mind, rumination, and distraction. Annals of Behavioral Medicine, 33(1), 11-21. https://doi.org/10.1207/s15324796abm3301_2 
Jansen, M., Heerkens, Y., Kuijer, W., van der Heijden, B., \& Engels, J. (2018). Effects of mindfulness-based stress reduction on employees' mental health: a systematic review. Plos One, 13(1), e0191332. https://doi.org/10.1371/ journal.pone.0191332

Josefsson, T., Lindwall, M., \& Broberg, A. G. (2014). The effects of a short-term mindfulness based intervention on self-reported mindfulness, decentering, executive attention, psychological health, and coping style: examining unique mindfulness effects and mediators. Mindfulness, 5(1), 18-35. https://doi.org/10.1007/s12671-012-0142-1

Kaplan, J. B., Bergman, A. L., Christopher, M., Bowen, S., \& Hunsinger, M. (2017). Role of resilience in mindfulness training for first responders. Mindfulness, 8, 1373-1380. https://doi.org/10.1007/s12671-017-0713-2

Kersemaekers, W., Rupprecht, S., Wittmann, M., Tamdjidi, C., Falke, P., Donders, R., ... Kohls, N. (2018). A workplace mindfulness intervention may be associated with improved psychological well-being and productivity: a preliminary field study in a company setting. Frontiers in Psychology, 9, 1-11. https://doi.org/10.3389/fpsyg.2018.00195

Keye, M. D., \& Pidgeon, A. M. (2013). An investigation of the relationship between resilience, mindfulness, and academic self-efficacy. Open Journal of Social Sciences, 1(6), 1-4. https://doi.org/10.4236/jss.2013.16001

Knorst, C. E. K. (2012). Resiliência: instrumentos de avaliação no contexto brasileiro (Monografia de especialização não-publicada). Universidade Federal do Rio Grande do Sul, Porto Alegre. Recuperado de https://www.lume.ufrgs. br/bitstream/handle/10183/40112/000826643.pdf?seque nce=1\&isAllowed=y

Kotsou, I. (2015). Caderno de exercícios de atenção plena. Petrópolis: Vozes.

Kwekkeboom, K. L., \& Gretarsdottir, E. (2006). Systematic review of relaxation interventions for pain. Journal of Nursing Scholarship, 38(3), 269-277. https://doi.org/10.1111/j.1547-5069.2006.00113.x

Li, Y., Wang, R., Tang, J., Chen, C., Tan, L., Wu, Z., ... Wang, X. (2015). Progressive muscle relaxation improves anxiety and depression of pulmonary arterial hypertension patients. Hindawi Publishing Corporation, 2015, 1-8. https://doi. org/10.1155/2015/792895

Luft, C. D. B., Sanches, S. O., Mazo, G. Z., \& Andrade, A. (2007). Versão brasileira da Escala de Estresse Percebido: tradução e validação para idosos. Revista de Saúde Pública, 41(4), 606-615. https://dx.doi.org/10.1590/S003489102007000400015

Luken, M., \& Sammons, A. (2016). Systematic review of mindfulness practice for reducing job burnout. American Journal of Occupational Therapy, 70(2), 1-10. https://doi.org/10.5014/ajot.2016.016956

Ministério da Fazenda. (2017). $1^{\circ}$ Boletim Quadrimestral sobre benefícios por incapacidade 2017: adoecimento mental e trabalho. Brasilia: Autor. Recuperado de http://sa.previdencia.gov.br/site/2017/04/1\%C2\%BA-boletim-quadrimestral. pdf

Ministério do Trabalho. (2018). Adoecimento ocupacional: um mal invisível e silencioso. Brasília: Autor. Recuperado de https://enit.trabalho.gov.br/portal/images/Cartilhas/Cartilha-doencas-ocupacionais.pdf

Moher, D., Hopewell, S., Schulz, K. F., Montori, V., Gøtzsche, P. C., Devereaux, P. J., ... Altman, D. G. (2010). CONSORT 2010 explanation and elaboration: updated guidelines for reporting parallel group randomised trials. Journal of Clinical Epidemiology, 63(9), e1-e37. https://doi.org/10.1016/j.jclinepi.2010.03.004

Oliveira, R. S., Trezza, B. M., Busse, A. L., \& Jacob Filho, W. (2014). Learning effect of computerized cognitive tests in older adults. Einstein, 12(2), 149-153. https://doi.org/10.1590/\$1679-45082014AO2954

Paschoal, T., \& Tamayo, Á. (2004). Validação da escala de estresse no trabalho. Estudos de Psicologia (Natal), 9(1), 45-52. https://doi.org/10.1590/S1413-294X2004000100006

Paulik, G., Simcocks, A., Weiss, L., \& Albert, S. (2010). Benefits of a 12-week mindfulness group program for mental health consumers in an outpatient setting. Mindfulness, 1(4), 215-226. https://doi.org/10.1007/s12671-010-0030-5

Pesce, R. P., Assis, S. G., Avanci, J. Q., Santos, N. C., Malaquias, J. V., \& Carvalhaes, R. (2005). Cross-cultural adaptation, reliability and validity of the resilience scale. Cadernos de Saúde Pública, 21(2), 436-448. https://doi.org/10.1590/ S0102-311X2005000200010

Qualidep. (1995). Projeto Whoqol-BREF. Porto Alegre: Universidade Federal do Rio Grande do Sul. Recuperado de https:// www.ufrgs.br/qualidep/qualidade-de-vida/projeto-whoqol-bref

Ribas, R. C., Moura, M. L. S., \& Hutz, C. S. (2004). Adaptação brasileira da Escala de Desejabilidade Social de MarloweCrowne. Avaliação Psicológica, 3(2), 83-92. Recuperado de http://pepsic.bvsalud.org/scielo.php?script=sci_ arttext\&pid=S1677-04712004000200003

Remor, E. (2006). Psychometric properties of a European Spanish version of the Perceived Stress Scale (PSS). The Spanish Journal of Psychology, 9(1), 86-93. https://doi.org/10.1017/S1138741600006004 
Rosado, I. V. M., Russo, G. H. A., \& Maia, E. M. C. (2015). Produzir saúde suscita adoecimento? As contradições do trabalho em hospitais públicos de urgência e emergência. Ciência e Saúde Coletiva, 20(10), 3021-3032. https://doi. org/10.1590/1413-812320152010.13202014

Rushton, C. H., Batcheller, J., Schroeder, K., \& Donohue, P. (2015). Burnout and resilience among nurses practicing in high-intensity settings. American Journal of Critical Care, 24(5), 412-420. https://doi.org/10.4037/ajcc2015291

Saeedi, M., Ashktorab, T., Saatchi, K., Zayeri, F., \& Amir, A. A. S. (2012). The effect of progressive muscle relaxation on sleep quality of patients undergoing hemodialysis. Iranian Journal of Critical Care Nursing, 5(1), 23-28. Retrieved from https://www.researchgate.net/publication/285848994_The_effect_of_progressive_muscle_relaxation_on_sleep_ quality_of_patients_undergoing_hemodialysis

Shahriari, M., Dehghan, M., Pahlavanzadeh, S., \& Hazini, A. (2017). Effects of progressive muscle relaxation, guided imagery and deep diaphragmatic breathing on quality of life in elderly with breast or prostate cancer. Journal of Education and Health Promotion, 6(1), 1-6. https://doi.org/10.4103/jehp.jehp_147_14

Silveira, S. G., \& Grisotti, M. (2011). Trabalho e saúde: um estudo sobre o processo saúde-doença dos servidores de um hospital universitário. Saúde e Transformação Social, 2(1), 18-27. Recuperado de https://www.researchgate.net/ publication/279489359_Trabalho_e_saude_um_estudo_sobre_o_processo_saude_doenca_dos_servidores_de_um_ hospital_universitario_Work_and_Health_study_about_health-disease_process_from_university_hospital_workers

Slomka, L. (2011). Associação entre o nível de resiliência e o estado clínico de pacientes renais crônicos em hemodiálise. Barbaroi, 34, 23-37. Recuperado de http://pepsic.bvsalud.org/scielo.php?script=sci_arttext\&pid=S0104-65782011000100003

Solhaug, I., Vibe, M., Friborg, O., Sørlie, T., Tyssen, R., Bjørndal, A., \& Rosenvinge, J. H. (2019). Long-term mental health effects of mindfulness training: a 4-year follow-up study. Mindfulness, 10, 1661-1672. https://doi.org/10.1007/ s12671-019-01100-2

Song, Y., \& Lindquist, R. (2015). Effects of mindfulness-based stress reduction on depression, anxiety, stress and mindfulness in Korean nursing students. Nurse Education Today, 35(1), 86-90. https://doi.org/10.1016/j.nedt.2014.06.010

Talarico, T. R. (2013). Qualidade de vida de pacientes deficientes auditivos adultos pré e pós-linguais usuários de implante coclear (Dissertação de mestrado não-publicada). Faculdade de Ciências Médicas da Santa Casa de São Paulo. Recuperado de https://www.fcmsantacasasp.edu.br/wp-content/uploads/dissertacoes-e-teses/ciencias-da-saude/2013Thais-Rodrigues-Talarico.pdf

Taylor, C., Harrison, J., Haimovitz, K., Oberle, E., Thomson, K., Schonert-Reichl, K., \& Roeser, R. W. (2016). Examining ways that a mindfulness-based intervention reduces stress in public school teachers: a mixed-methods study. Mindfulness, 7, 115-129. https://doi.org/10.1007/s12671-015-0425-4

Tsai, P.-S., Chen, P.-L., Lai, Y.-L., Lee, M.-B., \& Lin, C.-C. (2007). Effects of electromyography biofeedback-assisted relaxation on pain in patients with advanced cancer in a palliative care unit. Cancer Nursing, 30(5), 347-353. https:// doi.org/10.1097/01.NCC.0000290805.38335.7b

Veiga, G., Rodrigues, A., Lamy, E., Guiose, M., Pereira, C., \& Marmeleira, J. (2019). The effects of a relaxation intervention on nurses' psychological and physiological stress indicators: a pilot study. Complementary Therapies in Clinical Practice, 35, 265-271. https://doi.org/10.1016/j.ctcp.2019.03.008

Virgili, M. (2015). Mindfulness-based interventions reduce psychological distress in working adults: a meta-analysis of intervention studies. Mindfulness, 6(2), 326-337. https://doi.org/10.1007/s12671-013-0264-0

Visser, P. L., Hirsch, J. K., Brown, K. W., Ryan, R., \& Moynihan, J. A. (2015). Components of sleep quality as mediators of the relation between mindfulness and subjective vitality among older adults. Mindfulness, 6(2), 723-731. https:// doi.org/10.1007/s12671-014-0311-5

WHOQOL Group. (1994). Development of the WHOQOL: rationale and current status. International Journal of Mental Health, 23(3), 24-56. Retrieved from: https://www.jstor.org/stable/41344692?seq=1

Wongtongkam, N., Krivokapic-Skoko, B., Duncan, R., \& Bellio, M. (2017). The influence of a mindfulness-based intervention on job satisfaction and work-related stress and anxiety. International Journal of Mental Health Promotion, 19(3), 134-143. https://doi.org/10.1080/14623730.2017.1316760

Yaribeygi, H., Panahi, Y., Sahraei, H., Johnston, T. P., \& Sahebkar, A. (2017). The impact of stress on body function: a review. Excli Journal, 16, 1057-1072. http://dx.doi.org/10.17179/excli2017-480

Zeidan, F., Grant, J. A., Brown, C. A., McHaffie, J. G., \& Coghill, R. C. (2012). Mindfulness meditation-related pain relief: evidence for unique brain mechanisms in the regulation of pain. Neuroscience Letters, 520(2), 165-173. https://doi. org/10.1016/j.neulet.2012.03.082 